\title{
Adaptation to heat and exercise performance under cooler conditions: a new hot topic.
}

\section{Leading Article.}

Short title/ running head: Adaptation to heat and performance under cooler conditions

Jo Corbett (Corresponding author)

Department of Sport and Exercise Sciences

University of Portsmouth

Spinnaker Building

Cambridge Road

Portsmouth

PO1 2ER

United Kingdom

Tel: +44(0)2392843084 Fax: +44(0)02392843620 E-mail: jo.corbett@ port.ac.uk

Rebecca A. Neal

Department of Sport and Exercise Sciences

University of Portsmouth

Portsmouth

United Kingdom

E-mail: rebecca.neal@ port.ac.uk

Heather C. Lunt

Department of Sport and Exercise Sciences

University of Portsmouth

Portsmouth

United Kingdom

E-mail: heather.lunt@port.ac.uk

Michael J. Tipton

Department of Sport and Exercise Sciences

University of Portsmouth

Portsmouth

United Kingdom

E-mail: michael.tipton@port.ac.uk 


\begin{abstract}
Chronic exposure to a stressor elicits adaptations enhancing the tolerance to that stressor. These adaptive responses might also improve tolerance under less-stressful conditions. For example, historically there has been much interest in the adaptive responses to high-altitude, or hypoxia, and their ergogenic potential under sea-level, or normoxic, conditions. In contrast, the influence of the adaptive responses to heat on exercise under cooler conditions has received relatively little interest. Heat acclimation/acclimatization (HA) is known to increase work capacity in hot environments. Yet, aerobic exercise performance can progressively deteriorate as ambient temperature increases beyond $\sim 10^{\circ} \mathrm{C}$, indicating a thermal limitation even under relatively cool conditions. The improved thermoregulatory capability induced by HA might attenuate this thermal decrement in a manner similar to that seen when exposed to hotter temperatures. Moreover, the suite of adaptations elicited by HA has the potential to increase maximal oxygen uptake $\left(\mathrm{VO}_{2 \max }\right)$, lactate threshold (LT) and economy, and thus may be ergogenic even under conditions where performance is not thermally limited. Indeed, evidence is now emerging to support an ergogenic effect of HA, but the number of studies is limited and in some instances lack appropriate control, are confounded by methodological limitations, or do not address the mechanisms of action. Nevertheless, these tantalising insights into the ergogenic potential of heat will likely generate considerable interest in this new 'hot topic'. Future research will need to employ well designed studies to clarify the exercise conditions under which ergogenic effects of HA are apparent, to elucidate the precise mechanisms, and to optimise HA strategies for performance.
\end{abstract}




\section{Key Points}

- Heat acclimation/acclimatization (HA) is documented to improve aerobic exercise performance in hot environments.

- HA may also have the potential to increase performance under cooler conditions were there is a smaller, yet still potentially limiting, thermal burden.

- The adaptations induced by HA also have the potential to increase the maximal rate of oxygen uptake $\left(\mathrm{VO}_{2 \max }\right)$, lactate threshold (LT) and economy, and thus may be ergogenic through non-thermal mechanisms. 


\section{Introduction}

A perturbation to the stability of the internal environment when exposed to a stressor evokes effector responses to counter, or regulate, that perturbation. When repeated, these perturbations elicit adaptations enabling an individual to better control, or accommodate, the impact of a given stimulus on the body's internal environment, thereby enhancing the tolerance to that stimulus. When this process occurs as a consequence of stressors in the natural environment, and the ability to exercise in that environment is improved, it is termed acclimatization [1]. If these adaptations are induced through the use of an environmental chamber the term acclimation is used [1]; if all factors are identical in both environments then similar adaptation will result. In some circumstances the array of adaptive responses to a given stressor may also improve the tolerance under different [2, 3], or less stressful conditions [4, 5]. For instance, considerable attention has been devoted to the adaptive responses to high-altitude, or hypoxia, and the ergogenic potential for exercise performance under sea-level, or normoxic, conditions [6]. In contrast, the influence of the adaptive responses to heat on exercise performance under cooler conditions has received little interest. Although warm-weather training has long been popular with athletes, anecdotally it appears this was for comfort, convenience and logistical reasons rather than a direct effect of adaptation to heat per se.

\section{Adaptations to heat}

Heat acclimation/acclimatization (HA) is induced through repeated exposures to heat that are sufficient to elevate core temperature $\left(\mathrm{T}_{\mathrm{C}}\right)$ and skin temperature $\left(\mathrm{T}_{\mathrm{Sk}}\right)$ and promote sweating [7-14]. The first adaptations are complete within 3-6 days and have recently been reviewed [15]. Briefly, the initial adaptations are characterised by plasma volume expansion [14], underpinned by increased aldosterone secretion and sensitivity and intra-vascular protein influx $[12,14]$. These combined effects increase sodium and chloride reabsorption in sweat ducts and renal tubules, lowering sweat electrolyte content and increasing the osmotic/oncotic retention of water; red cell volume may also become increased with repeated heat exposure $[16,17]$. The resultant hypervolemia can increase stroke volume [12], lower heart rate at a given work-rate [7-11, 13], and increase maximal cardiac output [5], which may be aided by increases in myocardial efficiency [18] and ventricular compliance [19]. Sudomotor adaptions are evident from the second day of HA, but take 7-14 days for full development, and are characterised by a lowering of the sweating threshold [20] and greater sweating sensitivity [12, 20], leading to increased sweating [7-12]. The threshold for cutaneous vasodilatation is also reduced [20]. Together, these effects lower $\mathrm{T}_{\mathrm{Sk}}[7-10,13]$ and increase skin blood vessel compliance, which reduces cutaneous blood-flow for a given level of exercise [20] and helps to maintain perfusion pressure and improve cardiovascular stability. Metabolic adaptations also occur which reduce metabolic heat by increasing efficiency [11, 21] and decreasing muscle glycogen utilisation [22], as well as muscle and blood lactate accumulation [22-24]. Evidence is also emerging for an anabolic effect of heat [25-27]. These physiological changes likely underpin the reduction in perceived exertion which manifests following HA [13]. Overall, these adaptations result in improved defence of body temperature, characterised by a more favourable $\mathrm{T}_{\mathrm{C}}: \mathrm{T}_{\mathrm{Sk}}$ gradient [8], reduced $\mathrm{T}_{\mathrm{C}}[7-14]$, and a reduction in relative exercise intensity at a given work rate in the heat $[7-11,13]$, as well as an increased maximal rate of oxygen uptake $\left(\mathrm{VO}_{2 \max }\right)[5,11,17,28]$, lactate threshold (LT) [5], economy [11, 21], and increased work capacity under these conditions [5, 7, 12, 28, 29]. The similarity between the adaptive responses to heat and those occurring with exercise has long been recognised and endurance trained participants often demonstrate physiological adaptations associated with HA [30]. Nevertheless, there has been a growing recognition of 
the ergogenic potential of the adaptive response to heat under cooler conditions [5, 31-34] (Table 1). 
Table 1: Summary of thermoregulatory adaptations and the associated thermal and physiological effects following heat acclimation/acclimatization, as well as their ergogenic potential for aerobic exercise under cool or temperate conditions. $\uparrow=$ increased; $\downarrow$ decreased; $\checkmark=$ likely ergogenic potential; $\checkmark / x=$ ergogenic potential unclear.

\begin{tabular}{|c|c|c|}
\hline $\begin{array}{l}\text { Physiological adaptations following heat } \\
\text { acclimation/acclimatization }\end{array}$ & Effect & $\begin{array}{l}\text { Ergogenic potential under } \\
\text { cool/temperate conditions }\end{array}$ \\
\hline \multicolumn{3}{|l|}{ Thermoregulatory effects } \\
\hline Sweating (rate, sensitivity, threshold) & $\uparrow$ & $\checkmark / x$ \\
\hline Sweat electrolyte content & $\downarrow$ & $\checkmark / x$ \\
\hline Total body water & $\uparrow$ & $\checkmark / x$ \\
\hline Plasma volume & $\uparrow$ & $\sqrt{ } / x$ \\
\hline Red cell volume & $\uparrow$ & $\checkmark$ \\
\hline Total blood volume & $\uparrow$ & $\checkmark / x$ \\
\hline Skin blood-flow & $\downarrow$ & $\checkmark$ \\
\hline \multicolumn{3}{|l|}{ Thermal effects } \\
\hline Resting $\mathrm{T}_{\mathrm{C}}$ & $\downarrow$ & $\checkmark$ \\
\hline Sub-maximal exercise $T_{C}$ & $\downarrow$ & $\checkmark$ \\
\hline $\mathrm{T}_{\mathrm{Sk}}$ & $\downarrow$ & $\checkmark$ \\
\hline $\mathrm{T}_{\mathrm{C}}: \mathrm{T}_{\mathrm{Sk}}$ gradient & $\uparrow$ & $\checkmark$ \\
\hline \multicolumn{3}{|l|}{ Physiological effects } \\
\hline Heart rate at given sub-maximal work rate & $\downarrow$ & $\checkmark$ \\
\hline Myocardial efficiency & $\uparrow$ & $\checkmark$ \\
\hline Ventricular compliance & $\uparrow$ & $\checkmark$ \\
\hline Maximal cardiac output & $\uparrow$ & $\checkmark$ \\
\hline Maximal $\mathrm{O}_{2}$ uptake & $\uparrow$ & $\checkmark$ \\
\hline $\mathrm{O}_{2}$ uptake at sub-maximal work rate (economy) & $\downarrow$ & $\checkmark$ \\
\hline Carbohydrate metabolism & $\downarrow$ & $\checkmark$ \\
\hline Lactate threshold & $\uparrow$ & $\checkmark$ \\
\hline Anabolic effects & $\uparrow$ & $\checkmark$ \\
\hline Strength & $\uparrow$ & $\checkmark$ \\
\hline
\end{tabular}




\section{Ergogenic potential of HA \\ 3.1 Thermal effects}

The effect of ambient temperature on aerobic exercise performance is a continuum; the fastest performances are often achieved at a temperature of $\sim 10^{\circ} \mathrm{C}$ and performance slows exponentially as temperature increases beyond this optimum [35-37], although this will be influenced by other parameters influencing heat exchange, including the mode of exercise and climatic factors such as wind, humidity and radiation. In hot environments, diminished aerobic exercise performance likely results from the combined effects of increased temperature on the central nervous system [38, 39], peripheral nervous system [39], and possibly skeletal muscle [40], as well as augmented cardio-vascular strain caused by the need to maintain blood pressure in the face of competition for blood-flow between the heat loss requirements of the skin and the metabolic demands of the working muscles [41]. However, the relevance of these mechanisms under cooler conditions is less clear. It has been suggested that the high heat production of athletes means that they can exceed their 'prescriptive zone' [42], i.e. the range of ambient temperatures where the $\mathrm{T}_{\mathrm{C}}$ is dependent on metabolic rate and independent of the environmental temperature, even under cool conditions [37]. In a group of 13 competitive distance runners the mean (range) peak rectal temperature was 39.84 (39.39$40.28)^{\circ} \mathrm{C}$ during 8 -km running time-trials under cool conditions (wet bulb globe temperature [WBGT] $\sim 13^{\circ} \mathrm{C}$ ) [43], although the deleterious effect of a high $\mathrm{T}_{\mathrm{C}}$ without a co-existent high $\mathrm{T}_{\mathrm{Sk}}$ has been questioned [44]. Nevertheless, $\mathrm{T}_{\mathrm{Sk}}$ increases in proportion to ambient temperature and humidity [45]. This will augment skin blood-flow requirements [46], cardiovascular strain [44], and by extension, relative exercise intensity. It is tempting to speculate that the improved thermoregulatory capability induced by HA might attenuate this thermal decrement in a manner similar to that seen when exposed to hotter temperatures. Indeed, HA has been shown to lower $\mathrm{T}_{\mathrm{Sk}}$ and increase $\mathrm{T}_{\mathrm{C}}: \mathrm{T}_{\mathrm{Sk}}$ gradient during exercise in temperate $\left(23^{\circ} \mathrm{C}\right)$ [11] and cool conditions $\left(13^{\circ} \mathrm{C}\right)$ [5], with a reduction in heart rate, sweating rate, oxygen consumption and rectal temperature also reported in temperate conditions [11]. However, given that the deleterious impact of ambient temperature decreases exponentially, any ergogenic benefits of HA related to thermal tolerance might be anticipated to decline in parallel to the reduction in the thermal-burden of the environment.

\subsection{Non-thermal effects}

Some of the adaptive responses to heat may also have ergogenic potential through nonthermal mechanisms. For example, maximal cardiac output is increased in cool conditions following HA [5], possibly as a consequence of plasma volume expansion and a FrankStarling effect on stroke volume [47]. This effect may precipitate the increase in $\mathrm{VO}_{2 \max }$ reported in cool-temperate conditions following HA $[5,11,17,28]$, although the influence of plasma volume expansion on $\mathrm{VO}_{2 \max }$ is controversial in trained populations and depends on the balance between increased cardiac output and the haemodilution effect on $\mathrm{O}_{2}$ carrying capacity $[47,48]$. There is some evidence to suggest that red-cell mass may also increase following exposure to heat $[16,17]$, whereas improved myocardial efficiency [18] and an increased end-diastolic volume as a consequence of increased ventricular compliance [19] could also account for the increase in $\mathrm{VO}_{2 \max }$. An increase in $\mathrm{VO}_{2 \max }$ will decrease the relative exercise intensity at any given work-rate and this effect will be augmented by the improved exercise economy demonstrated in cool conditions following HA [21]. The mechanism underpinning the improved economy is unclear, although a transition from fast myosin to the more efficient slow myosin form has been demonstrated following HA in rat cardiac muscle [49]. Increased strength has also been reported following HA with exercise [50], and with local muscle heating [25], which might occur via heat-induced activation of the anabolic mammalian target of rapamycin (mTOR) pathway [26]. Increased strength 
would reduce the relative force of a given muscle contraction. Although speculative, each of these effects could contribute to the increased power at the LT during exercise in a cool environment that has been reported following HA [5], but this could also be attributed to reduced carbohydrate metabolism demonstrated during exercise in a cool environment following HA [24], or dilution effects due to plasma volume expansion. Equally, altered lactate kinetics could be a result of improved $\mathrm{O}_{2}$ supply as a consequence of the increase in $\mathrm{VO}_{2 \max }$, or better preservation of splanchnic lactate removal as a consequence of increased cardiac output, as suggested by Lorenzo et al. [5]. Regardless of the mechanisms, endurance sports performance is underpinned by the interaction of $\mathrm{VO}_{2 \max }$, the percentage of $\mathrm{VO}_{2 \max }$ that can be sustained for a given duration which is closely linked to the LT, and economy [51]; the observation that each of these may be positively influenced by adaptation to heat is indicative of a powerful ergogenic potential. Nevertheless, the ergolytic potential of HA should also be acknowledged. The mass penalty associated with hypervolemia could offset any physiological benefits, particularly in weight-bearing sports, although simple calculations based on a $70 \mathrm{~kg}$ male suggest that this effect would be no greater than $\sim 0.3 \mathrm{~kg}$, and likely less given that plasma volume expansion may occur in the absence of body mass change, possibly at the expense of the interstitial fluid volume [12]. Likewise, increased sweating rates will accelerate dehydration, although this is unlikely to be a problem if fluids are freely available because humans may be able to maintain adequate hydration with ad-libitum fluid consumption [52] and HA also improves thirst sensitivity [53].

\section{State of the literature}

To date, a limited number of studies have examined the ergogenic potential of HA (Table 2). Sawka et al. [28] were first to show an ergogenic effect of HA, in a group of soldiers undertaking nine, consecutive, daily 90 -minute heat exposures $\left(49^{\circ} \mathrm{C}, 20 \%\right.$ relative humidity $[\mathrm{RH}])$ with light exercise. Reductions in $\mathrm{T}_{\mathrm{C}}$ and heart rate were evident in the final acclimation session, indicating $\mathrm{HA}$, and an incremental cycling exercise test showed that mean peak power output and $\mathrm{VO}_{2 \max }$ were increased under the same ambient conditions, but increases in mean peak power $(4 \%)$ and $\mathrm{VO}_{2 \max }(4 \%)$ were also evident under cooler conditions $\left(21^{\circ} \mathrm{C}, 30 \% \mathrm{RH}\right)$. However, this study did not include a control group and whilst the work-rate used during the HA programme was lighter than that typically associated with a training effect in fit participants [54], the potential for training effects cannot be excluded, although others have also demonstrated an effect of $\mathrm{HA}$ on $\mathrm{VO}_{2 \max }$, with [5], or without [11, 17], a concomitant ergogenic effect.

Unfortunately, the absence of an appropriate control group is common feature of 5 of the 7 studies reporting an ergogenic effect of heat exposure on exercise under cooler conditions $[28,31,33,34,55]$. For instance, a $7-44 \%$ mean increase in run distance during a yo-yo shuttle running test conducted at an ambient temperature of $\sim 22-23^{\circ} \mathrm{C}$ has been reported following a 7- [31] or 14-day [33, 34] training camp, during which athletes were frequently exposed to hot conditions $\left(33-40^{\circ} \mathrm{C}, 27-50 \% \mathrm{RH}\right)$ with, and without, exercise. In two of these studies some of the participants were also exposed to hypoxic conditions whilst sleeping [33, 34], although the responses were largely similar irrespective of hypoxic exposure. Similarly, a $10 \%$ mean improvement in 400-m swim time was reported after undertaking an 8-day warm-weather swim training camp (air temperature $30^{\circ} \mathrm{C}, 80 \% \mathrm{RH}$ ) during which the athletes swam a mean $\pm \mathrm{SD}$ distance of $62.3 \pm 3.4 \mathrm{~km}$ (water temperature $30^{\circ} \mathrm{C}$ ) [55]. However, this ergogenic effect was only evident 40-days after the training camp and not 10-days after the training camp, whereas another study [33] reported an ergogenic effect immediately after the training camp, which persisted 28-days after the training camp. These sustained effects are interesting because they are not consistent with the typical time-course for the decay in 
physiological adaptation reported following HA [1, 15]. Indeed, whilst some of these studies demonstrated physiological effects consistent with some form of adaptation to heat, such as plasma volume expansion [31, 33, 34], reduced heart rate and reduced sweat-sodium concentration $[33,34]$, and lowering of $\mathrm{T}_{\mathrm{Sk}}[34]$ during exercise in the heat, $\mathrm{T}_{\mathrm{C}}$ was either unchanged [34], or not reported [31, 33, 55]. Moreover, the ergogenic effect was either not correlated, or weakly correlated, with the markers of HA [34]. Taken together, the absence of an appropriate control group, the limited evidence for HA, the weak relationship between HA markers and the change in performance, and prolonged ergogenic effects at odds with the reported decay in HA, means that the extent to which the ergogenic effects in these studies is underpinned by HA, training effects, or the interaction of HA and training, is not clear.

Two studies investigating the effect of heat exposure on aerobic exercise performance in cooler conditions have employed randomised controlled trials experimental designs with a 2[56] or 3-week [16] washout period, but given the sustained ergogenic effects reported in some studies $[33,55]$, this washout period may have been insufficient. Following a 7-day HA programme $\left(37^{\circ} \mathrm{C}, 50 \% \mathrm{RH}\right)$ consisting of a combination of fixed work-rate (days 1 and 7 ) and self-paced exercise (days 2-6) for $90 \mathrm{~min} \cdot \mathrm{day}^{-1}$, Morrison et al. [56] demonstrated a $0.4 \%$ mean improvement (adjusted for learning effects) in 40-km cycling time-trial performance in cool conditions $\left(20^{\circ} \mathrm{C}, 50 \% \mathrm{RH}\right)$, with a $35 / 54 / 11 \%$ chance that the effect was beneficial/trivial/harmful. However, the thermal stimulus induced by the HA programme in this study may have been insufficient, with the self-paced exercise resulting in similar mean $\mathrm{T}_{\mathrm{C}}$ in the HA group $\left(\mathrm{T}_{\mathrm{C}}=38.1^{\circ} \mathrm{C}\right)$ and the control group $\left(\mathrm{T}_{\mathrm{C}}=38.0^{\circ} \mathrm{C}\right)$ exercising in cooler conditions. In both instances the $\mathrm{T}_{\mathrm{C}}$ was lower than that associated with optimal HA [57] and although there was some evidence of modest HA, as shown by a small reduction in haematocrit, heart rate, sweat rate and $\mathrm{T}_{\mathrm{C}}$ from day 1 to 7 , the correlation between these effects and performance changes was weak. Scoon et al. [16] employed a 3-week intervention in which trained distance runners undertook $\sim 12, \sim 30$-minute, saunas following their normal training, and a control condition in which participants undertook their normal training without sauna. Whilst HA was not assessed per se, and optimal HA might require exercise during exposure to heat [58], significant increases in plasma, red cell and total blood volume were evident following the sauna intervention and mean run time to exhaustion at $\sim 5,000$-m running pace was increased by $32 \%$. Although the ambient conditions of the run to exhaustion were not stated it is highly likely that they were substantially lower than the sauna conditions and the individual changes in performance were strongly correlated with the plasma $(r=0.96)$ and total blood volume $(r=0.94)$ changes. However, caution is warranted when interpreting the magnitude of improvement from tests to exhaustion given that the equivalent effect on performance in a time-trial of a similar duration will be less [59].

In each of the aforementioned studies [16, 28, 31, 33, 34, 55] the ambient conditions were likely above those associated with optimal performance during sustained exercise [35-37], indicating a potentially limiting thermal burden in many of these studies, even under the cooler conditions. Whilst this does not impact upon the practical benefits of HA for exercise under these conditions, it may obscure the mechanisms underpinning the ergogenic effects of HA. To date, only one study demonstrating an ergogenic effect of HA has done so under ambient conditions associated with optimal aerobic performance. Lorenzo et al. [5] demonstrated that the adaptive responses elicited by a 10 day HA programme consisting of 90-minutes exercise per day $\left(50 \% \mathrm{VO}_{2 \max }\right)$ in a hyperthermic environment $\left(40^{\circ} \mathrm{C}, 30 \% \mathrm{RH}\right)$ increased the amount of work done in a 60-minute cycling trial by a mean of $6 \%$ under cool $\left(13^{\circ} \mathrm{C}, 30 \% \mathrm{RH}\right)$ conditions in well-trained cyclists, but given that during cycling exercise in the field the power output is related to velocity with an exponent of between 2.6 and 3 [ 60 , 
61], the true performance effect in an outdoor time-trial would be somewhat lower. Nevertheless, the HA was effective as evidenced by a significant plasma volume expansion, a reduction in exercise heart rate and $\mathrm{T}_{\mathrm{C}}$, and improved exercise performance under the hot conditions with the improvement in cool performance accompanied by increases in mean maximal cardiac output $(9.1 \%), \mathrm{VO}_{2 \max }(5 \%)$, and power at $\mathrm{LT}(5 \%)$ in these conditions. Moreover, a control group undertaking the same exercise protocol under cooler conditions did not show these effects, indicating that the responses were probably caused by adaptation to heat, or an interaction between heat and exercise, rather than exercise, although the influence of heat on relative exercise intensity means that the potential for an augmented training effect in the experimental group remains possible. 
Table 2: Human studies reporting effects of repeated heat exposure on exercise performance and performance related measures under cooler conditions. Ambient conditions are dry bulb temperature and humidity (if reported). Cooler exercise performance refers to tests completed within five days of heat exposure period unless otherwise stated. Heat exposures are laboratory based unless otherwise stated e.g. training camp, sauna. All effects are reported as group mean values.

\begin{tabular}{|c|c|c|c|c|c|c|}
\hline Study & Participants & Heat exposure & Control group & $\begin{array}{l}\text { Cooler exercise } \\
\text { performance }\end{array}$ & Effect & $\begin{array}{l}\text { Statistical } \\
\text { significance }\end{array}$ \\
\hline $\begin{array}{l}\text { Sawka et al. } \\
{[28]}\end{array}$ & 13 soldiers & $\begin{array}{l}9 \text { consecutive days, } 120 \mathrm{~min} \cdot \text { day }^{-1}\left(49^{\circ} \mathrm{C}, 20 \%\right. \\
\mathrm{RH}) \text { with exercise }\left(40-50 \% \mathrm{VO}_{2 \max }\right)\end{array}$ & None & $\begin{array}{l}\text { Ramp exercise test } \\
\left(21^{\circ} \mathrm{C}, 30 \% \mathrm{RH}\right)\end{array}$ & $\begin{array}{l}4 \% \text { increase in } \mathrm{VO}_{2 \max } \\
4 \% \text { increase in ramp test } \\
\text { peak power output (both } \\
\text { relative to pre heat exposure) }\end{array}$ & $\begin{array}{l}\mathrm{p}<0.01 \\
\mathrm{p}<0.05\end{array}$ \\
\hline $\begin{array}{l}\text { Morrison et al. } \\
\text { [56] }\end{array}$ & $\begin{array}{l}9 \text { highly trained } \\
\text { cyclists }\end{array}$ & $\begin{array}{l}7 \text { consecutive days, } 90 \mathrm{~min} \cdot \text { day }^{-1}\left(37^{\circ} \mathrm{C}, 50 \%\right. \\
\mathrm{RH}) \text { with exercise (day } 1 \text { and } 7 \text { at } 45 \% \text { maximum } \\
\text { power from } \mathrm{VO}_{2 \max } \text { test, days } 2-6 \text { self-paced) }\end{array}$ & $\begin{array}{l}\text { RCT with two week washout: } 7 \text { days, } 90 \\
\text { min. day }{ }^{-1}\left(20^{\circ} \mathrm{C}, 50 \% \mathrm{RH}\right) \text { at matched } \\
\text { absolute work rate (day } 1 \text { and } 7) \text {, or RPE } \\
\text { (day 2-6) }\end{array}$ & $\begin{array}{l}\text { 40-km cycling time-trial } \\
\left(20^{\circ} \mathrm{C}, 50 \% \mathrm{RH}\right)\end{array}$ & $\begin{array}{l}0.4 \% \text { faster relative to } \\
\text { control }^{\mathrm{a}}\end{array}$ & $\begin{array}{l}\text { Not } \\
\text { reported }^{\mathrm{b}}\end{array}$ \\
\hline Hue et al. [55] & $\begin{array}{l}6 \text { trained } \\
\text { regional/inter- } \\
\text { regional } \\
\text { swimmers }\end{array}$ & $\begin{array}{l}8 \text { consecutive days (training camp, } \sim 30^{\circ} \mathrm{C}, 80 \% \\
\mathrm{RH}), 14 \text { swim training sessions }\left(30^{\circ} \mathrm{C} \text { water) }\right.\end{array}$ & None $^{\mathrm{c}}$ & $\begin{array}{l}400-\mathrm{m} \text { maximal swim test } \\
10 \text { and } 30 \text { days post heat } \\
\text { exposure }\left(27.1^{\circ} \mathrm{C} \text { water }\right)\end{array}$ & $\begin{array}{l}10 \% \text { faster } 30 \text { days post heat } \\
\text { exposure relative to pre heat } \\
\text { exposure }\end{array}$ & $\mathrm{p}<0.03$ \\
\hline $\begin{array}{l}\text { Scoon et al. } \\
\text { [16] }\end{array}$ & $\begin{array}{l}6 \text { trained } \\
\text { distance runners } \\
\text { and triathletes }\end{array}$ & $\begin{array}{l}3 \text { wks usual running training with mean } \pm \text { SD } 7 \\
\pm 2.1 \text { saunas }\left(\sim 90^{\circ} \mathrm{C} \text {, 'humid', mean } \pm \mathrm{SD}\right. \\
\text { duration of } 31 \pm 5 \mathrm{~min}) \text { immediately after } \\
\text { training }\end{array}$ & $\begin{array}{l}\text { RCT with } 3 \text { wk washout: } 3 \text { wks usual } \\
\text { training, no sauna }\end{array}$ & $\begin{array}{l}\text { Run time to exhaustion at } \\
\text { current best } 5 \mathrm{~km} \text { speed } \\
\text { (ambient temperature not } \\
\text { reported) }\end{array}$ & $\begin{array}{l}32 \% \text { increase in run time to } \\
\text { exhaustion relative to control }\end{array}$ & $\begin{array}{l}\text { Not } \\
\text { reported }^{\mathrm{d}}\end{array}$ \\
\hline \multirow[t]{3}{*}{$\begin{array}{l}\text { Lorenzo et al. } \\
{[5]}\end{array}$} & \multirow{3}{*}{$\begin{array}{l}12 \text { highly } \\
\text { trained } \\
\text { endurance } \\
\text { cyclists }\end{array}$} & \multirow{3}{*}{$\begin{array}{l}10 \text { consecutive days, } 100 \mathrm{~min} \cdot \mathrm{day}^{-1}\left(40^{\circ} \mathrm{C}, 30 \%\right. \\
\mathrm{RH}) \text { with exercise }\left(2 \times 45 \mathrm{~min} \text { at } 50 \% \mathrm{VO}_{2 \max },\right. \\
10 \text { min recovery) plus usual training }\end{array}$} & \multirow{3}{*}{$\begin{array}{l}8 \text { highly trained endurance cyclists (four also } \\
\text { undertook experimental condition; washout } \\
\text { not reported): } 10 \text { days; } 100 \mathrm{~min} \cdot \mathrm{day}^{-1}\left(13^{\circ} \mathrm{C}\right. \\
\text { and } 30 \% \mathrm{RH}) \text { with exercise }(2 \times 45 \mathrm{~min} \text { at } \\
50 \% \mathrm{VO}_{2 \max }, 10 \text { min recovery) plus usual } \\
\text { training }\end{array}$} & 60 min cycling time-trial & $\begin{array}{l}6 \% \text { increase in time-trial } \\
\text { work }\end{array}$ & $\mathrm{p}=0.005$ \\
\hline & & & & LT test & & $\mathrm{p}=0.002$ \\
\hline & & & & $\begin{array}{l}\mathrm{VO}_{2 \max } \text { test } \\
\left(13^{\circ} \mathrm{C}, 30 \% \mathrm{RH}\right)\end{array}$ & $\begin{array}{l}5 \% \text { increase in } \mathrm{VO}_{2 \max } \text { (all } \\
\text { relative to pre heat exposure })\end{array}$ & $\mathrm{p}=0.004$ \\
\hline $\begin{array}{l}\text { Buchheit } \text { et al. } \\
\text { [31] }\end{array}$ & $\begin{array}{l}15 \text { competitive } \\
\text { soccer players }\end{array}$ & $\begin{array}{l}7 \text { consecutive days (training camp), } 60-95 \\
\text { min. day }{ }^{-1}\left(\sim 40^{\circ} \mathrm{C}, 27 \% \mathrm{RH} .\right) \text {, with exercise (50- } \\
83 \% \text { heart rate max) }\end{array}$ & None & $\begin{array}{l}\text { Yo-Yo intermittent } \\
\text { recovery test level } 1 \\
\left(\sim 22^{\circ} \mathrm{C}, 50 \% \mathrm{RH}\right)\end{array}$ & $7 \%$ increase in run distance & $\mathrm{p}=0.009$ \\
\hline $\begin{array}{l}\text { Buchheit et al. } \\
\text { [33] }\end{array}$ & $\begin{array}{l}17 \text { professional } \\
\text { Australian } \\
\text { Rules Football } \\
\text { players }\end{array}$ & $\begin{array}{l}14 \text { consecutive days (training camp), } 10 \text { football } \\
\text { skills training sessions }(\sim 70 \text { min mean duration, } \\
\left.29-33^{\circ} \mathrm{C}, 37-50 \% \mathrm{RH}\right) \text { plus } 15 \mathrm{~h} \text { total incidental } \\
\text { heat exposure and } \sim 13 \mathrm{~h} \text { total, additional } \\
\text { interval/strength training }\left(\sim 23^{\circ} \mathrm{C}, 55 \% \mathrm{RH}\right)^{\mathrm{f}}\end{array}$ & None & $\begin{array}{l}\text { Yo-Yo intermediate } \\
\text { recovery level } 2 \text { test } \\
\left(\sim 22-23^{\circ} \mathrm{C}\right)\end{array}$ & $\begin{array}{l}44 \% \text { increase in run distance, } \\
\text { run distance also increased } 4 \\
\text { weeks post- intervention }\end{array}$ & $\begin{array}{l}\text { Not } \\
\text { reported }\end{array}$ \\
\hline $\begin{array}{l}\text { Racinais et al. } \\
\text { [34] }\end{array}$ & $\begin{array}{l}18 \text { professional } \\
\text { Australian } \\
\text { Rules Football } \\
\text { players }\end{array}$ & $\begin{array}{l}14 \text { consecutive days (training camp), } 10 \text { football } \\
\text { skills training sessions }(\sim 90 \text { min mean duration, } \\
\left.29-33^{\circ} \mathrm{C}, 37-50 \% \mathrm{RH}\right) \text { plus additional strength } \\
\text { and conditioning sessions }\left(\sim 22^{\circ} \mathrm{C}\right)^{\mathrm{h}}\end{array}$ & None & $\begin{array}{l}\text { Yo-Yo intermediate } \\
\text { recovery level } 2 \text { test } \\
\left(23^{\circ} \mathrm{C}\right)\end{array}$ & $44 \%$ increase in run distance & $\mathrm{p}<0.001$ \\
\hline
\end{tabular}




\section{Future Directions}

Although a growing number of studies have reported an ergogenic effect of HA, these findings have often been confounded by the absence of an appropriate control group [28, 31, $33,34,55]$, sub-optimal HA programme [16, 56], absence of evidence for a clear HA [16, 31, $33,34,55,56]$, coincident hypoxic exposures [33, 34], and the use of exercise models where the 'true' performance effect is unclear [5, 16, 28, 31, 33, 34]. Thus, further studies are needed to clearly establish the ergogenic potential of HA during aerobic exercise, particularly in individuals who are highly endurance trained and may already demonstrate pronounced HA. Likewise, whilst there is evidence that HA can improve repeated sprint ability in the heat [29], the effect of HA on shorter durations of exercise and intermittent exercise under more temperate conditions has not been examined. However, as interest in the ergogenic effects of HA increases among athletes the potential for placebo effects will increase and researchers will need to be aware of this. Moreover, in the majority of studies, the ergogenic effect has been demonstrated under conditions that may still pose a limiting thermal burden $[16,28,31$, $33,34,55,56]$. Although this does not detract from the practical significance of these findings, it may partially obscure the mechanisms underpinning the reported ergogenic effects; understanding the mechanisms by which adaptation to heat can enhance performance under cooler conditions is key for developing and optimising effective intervention strategies.

Currently, it appears that haematological changes occurring with HA could be important [5, $16,17]$. Recent evidence suggests that permissive dehydration during HA can lead to greater plasma volume expansion [62], although if the associated increases in cardiac output do not offset any haemodilution [48], or outweigh the potential for small changes in body mass, then performance could be impaired. There is a growing interest in the effects of combined stressors, such as heat and hypoxia [17, 63] and evidence is emerging to support such an ergogenic 'cocktail' [33], but given the multitude of physiological adaptations with singleenvironmental stressors, clarifying and isolating precise mechanisms of any performance effects with combined-stressors will likely be challenging. Understanding the time course for the onset and decay of any ergogenic effects, and the frequency of stimulus required for maintenance is vital for developing strategies that can be used by athletes. It is generally agreed that HA is improved when heat exposure is combined with exercise [58], but given the ergogenic effects reported following sauna, it is not clear if this is also the case for the use of HA to optimise exercise performance under cooler conditions. This is important because the external work rate is typically reduced during exercise in the heat, which may compromise training stimulus in a manner similar to that seen at altitude and could lead to the development of a 'live-hot train-cool' strategy. To date, the controlled-hyperthermia technique, which better maintains the thermal stress and may optimise HA $[15,57]$, has not been employed in studies examining the ergogenic potential of heat.

\section{Conclusion}

The adaptive responses to heat improve aerobic exercise performance in hot conditions, but also have the potential to enhance exercise performance under cooler conditions. In some situations aerobic exercise performance can deteriorate as ambient temperature increases beyond $\sim 10^{\circ} \mathrm{C}$, indicating a thermal limitation even under relatively cool conditions. The improved thermoregulatory capability induced by HA might attenuate this thermal decrement in a manner similar to that seen when exposed to hotter temperatures. However, the suite of adaptations elicited by HA have the potential to increase $\mathrm{VO}_{2 \max }$, LT and economy, and thus may be ergogenic even under conditions where performance is not thermally limited. A small number of studies have reported an ergogenic effect of HA on exercise performance under cooler condition, although there remains a need for further studies in order to isolate and 
confirm these effects. Similarly, more research is needed to clarify the mechanisms of any ergogenic effects of HA. This will, in turn pave the way for the development of strategies optimising the induction and maintenance of any ergogenic effects of HA. The ergogenic effect of HA is an area with immense promise and will likely prove to be a fruitful new 'hot topic'. 


\section{Acknowledgements}

The authors have no conflicts of interest to declare. R.A Neal receives a bursary joint funded by UK Sport and University of Portsmouth. 


\section{References}

1 Armstrong LE, Maresh CM. The induction and decay of heat acclimatisation in trained athletes. Sports Med. 1991;12:302-312.

2 Horowitz M. Heat acclimation and cross-tolerance against novel stressors: genomicphysiological linkage. Prog Brain Res. 2007;162:373-392.

3 Lunt HC, Barwood MJ, Corbett J, et al. 'Cross-adaptation': habituation to short repeated cold-water immersions affects the response to acute hypoxia in humans. J Physiol. 2010;588:3605-3613.

4 Stray-Gundersen J, Chapman RF, Levine BD. "Living high-training low" altitude training improves sea level performance in male and female elite runners. $J$ Appl Physiol. 2001;91:1113-1120.

5 Lorenzo S, Halliwill JR, Sawka MN, et al. Heat acclimation improves exercise performance. J Appl Physiol. 2010;109:1140-1147.

6 Bonetti DL, Hopkins WG. Sea-level exercise performance following adaptation to hypoxia. Sports Med. 2009;39:107-127.

7 Robinson S, Turrell ES, Belding HS, et al. Rapid acclimatization to work in hot climates. Am J Physiol. 1943;140:168-176.

8 Wyndham $\mathrm{CH}$. Effect of acclimatization on circulatory responses to high environmental temperatures. J Appl Physiol. 1951;4:383-395.

9 Lind AR, Bass DE. Optimal exposure time for development of acclimatization to heat. Fed Proc. 1962;22:704-708.

10 Wyndham $\mathrm{CH}$, Rogers GG, Senay LC, et al. Acclimization in a hot, humid environment: cardiovascular adjustments. J Appl Physiol. 1976;40:779-785.

11 Shvartz E, Shapiro Y, Magazanik A, et al. Heat acclimation, physical fitness, and responses to exercise in temperate and hot environments. J Appl Physiol Respir Environ Exerc Physiol. 1977;43:678-683.

12 Nielsen B, Hales JR, Strange S, et al. Human circulatory and thermoregulatory adaptations with heat acclimation and exercise in a hot, dry environment. J Physiol. 1993;460:467-485.

13 Weller AS, Linnane DM, Jonkman AG, et al. Quantification of the decay and reinduction of heat acclimation in dry-heat following 12 and 26 days without exposure to heat stress. Eur J Appl Physiol. 2007;102:57-66.

14 Senay LC, Mitchell D, Wyndham CH. Acclimatization in a hot, humid environment: body fluid adjustments. J Appl Physiol. 1976;40:786-796. 
15 Garrett AT, Rehrer NJ, Patterson MJ. Induction and decay of short-term heat acclimation in moderately and highly trained athletes. Sports Med. 2011;41:757-771.

16 Scoon GS, Hopkins WG, Mayhew S, et al. Effect of post-exercise sauna bathing on the endurance performance of competitive male runners. J Sci Med Sport. 2007;10:259-262.

17 Takeno Y, Kamijo YI, Nose H. Thermoregulatory and aerobic changes after endurance training in a hypobaric hypoxic and warm environment. J Appl Physiol. 2001;91:1520-1528.

18 Horowitz M, Parnes S, Hasin Y. Mechanical and metabolic performance of the rat heart: effects of combined stress of heat acclimation and swimming training. J Basic Clin Physiol Pharmacol. 1993;4:139-156.

19 Horowitz M, Shimoni Y, Parnes S, et al. Heat acclimation: cardiac performance of isolated rat heart. J Appl Physiol. 1986;60:9-13.

20 Roberts MF, Wenger CB, Stolwijk JA, et al. Skin blood flow and sweating changes following exercise training and heat acclimation. J Appl Physiol. 1977;43:133-137.

21 Sawka MN, Pandolf KB, Avellini BA, et al. Does heat acclimation lower the rate of metabolism elicited by muscular exercise? Aviat Space Environ Med. 1983;54:27-31.

22 Kirwan JP, Costill DL, Kuipers H, et al. Substrate utilization in leg muscle of men after heat acclimation. J Appl Physiol. 1987;63:31-35.

23 Febbraio MA, Snow RJ, Hargreaves M, et al. Muscle metabolism during exercise and heat stress in trained men: effect of acclimation. J Appl Physiol. 1994;76:589-597.

24 Young AJ, Sawka MN, Levine L, et al. Skeletal muscle metabolism during exercise is influenced by heat acclimation. J Appl Physiol. 1985;59:1929-1935.

25 Goto $\mathrm{K}$, Oda $\mathrm{H}$, Kondo $\mathrm{H}$, et al. Responses of muscle mass, strength and gene transcripts to long-term heat stress in healthy human subjects. Eur J Appl Physiol. 2011;111:17-27.

26 Kakigi R, Naito H, Ogura $\mathrm{Y}$, et al. Heat stress enhances mTOR signaling after resistance exercise in human skeletal muscle. J Physiol Sci. 2011;61:131-140.

27 Yoshihara T, Naito H, Kakigi R, et al. Heat stress activates the Akt/mTOR signalling pathway in rat skeletal muscle. Acta Physiol (Oxf). 2013;207:416-426.

28 Sawka MN, Young AJ, Cadarette BS, et al. Influence of heat stress and acclimation on maximal aerobic power. Eur J Appl Physiol Occup Physiol. 1985;53:294-298.

29 Castle P, Mackenzie RW, Maxwell N, et al. Heat acclimation improves intermittent sprinting in the heat but additional pre-cooling offers no further ergogenic effect. J Sport Sci. 2011;29:1125-1134. 
30 Piwonka RW, Robinson S, Gay VL, et al. Preacclimatization of men to heat by training. J Appl Physiol. 1965;20:379-383.

31 Buchheit M, Voss SC, Nybo L, et al. Physiological and performance adaptations to an in-season soccer camp in the heat: Associations with heart rate and heart rate variability. Scand J Med Sci Sports. 2011;21:e477-e485.

32 Sawka MN. Career perspectives of Michael N. Sawka. Extrem Physiol Med. 2012;1:1-10.

33 Buchheit M, Racinais S, Bilsborough J, et al. Adding heat to the live-high train-low altitude model: a practical insight from professional football. B J Sports Med. 2013;47(Suppl 1):i59-i69.

34 Racinais S, Buchheit M, Bilsborough J, et al. Physiological and performance responses to a training-camp in the heat in professional Australian football players. Int $\mathbf{J}$ Sports Physiol Perf. 2013; [Epub ahead of print]

35 Galloway SD, Maughan RJ. Effects of ambient temperature on the capacity to perform prolonged cycle exercise in man. Med Sci Sports Exerc. 1997;29:1240-1249.

36 Ely MR, Cheuvront SN, Roberts WO, et al. Impact of weather on marathon-running performance. Med Sci Sports Exerc. 2007;39:487-493.

37 Ely MR, Martin DE, Cheuvront SN, et al. Effect of ambient temperature on marathon pacing is dependent on runner ability. Med Sci Sports Exerc. 2008;40:1675-1680.

38 Nybo L. Cycling in the heat: performance perspectives and cerebral challenges. Scand J Med Sci Sports. 2010;20:71-79.

39 Périard JD, Christian RJ, Knez WL, et al. Voluntary muscle and motor cortical activation during progressive exercise and passively induced hyperthermia. Exp Physiol, 2014;99:136-148.

40 Todd G, Butler JE, Taylor JL, et al. Hyperthermia: a failure of the motor cortex and the muscle. J Physiol. 2005;563: 621-631.

41 Rowell LB. Human cardiovascular adjustments to thermal stress. Physiol Rev. $1974 ; 54: 75-159$

42 Lind AR. A physiological criterion for setting thermal environmental limits for everyday work. J Appl Physiol.1963;18:51-56.

43 Ely BR, Ely MR, Cheuvront SN, et al. Evidence against a $40^{\circ} \mathrm{C}$ core temperature threshold for fatigue in humans. J Appl Physiol. 2009;107:1519-1525.

44 Sawka MN, Cheuvront SN, Kenefick RW. High skin temperature and hypohydration impair aerobic performance. Exp Physiol. 2012;97:327-332. 
45 Gagge AP Gonzalez RR. Mechanisms of heat exchange: biophysics and physiology. In: Fregly MJ Blatteis CM editors. Handbook of Physiology. Bethesda, MD: American Physiological Society; 1996. pp. 45-84.

46 Rowell LB, Murray JA, Brengelmann GL, et al. Human cardiovascular adjustments to rapid changes in skin temperature during exercise. Circ Res. 1969;24:711-724.

47 Krip B, Gledhill N, Jamnik V, et al. Effect of alterations in blood volume on cardiac function during maximal exercise. Med Sci Sports Exerc. 1997;29:1469-1476.

48 Coyle EF, Hopper MK, Coggan AR. Maximal oxygen uptake relative to plasma volume expansion. Int J Sports Med. 1990;11:116-119.

49 Horowitz M, Peyser YM, Muhlrad A. Alterations in cardiac myosin isoenzymes distribution as an adaptation to chronic environmental heat stress in the rat. J Mol Cell Cardiol. 1986;18:511-515.

50 Kodesh E, Horowitz M. Soleus adaptation to combined exercise and heat acclimation: physiogenomic aspects. Med Sci Sports Exerc. 2010;42:943-952.

51 Joyner MJ, Coyle EF. Endurance exercise performance: the physiology of champions. J Physiol. 2008;586:35-44.

52 Nolte HW, Noakes TD, van Vuuren B. Protection of total body water content and absence of hyperthermia despite $2 \%$ body mass loss ('voluntary dehydration') in soldiers drinking ad libitum during prolonged exercise in cool environmental conditions. B J Sports Med. 2011; 45:1106-1112.

53 Eichna LW, Park CR, Nelson N, et al. Thermal regulation during acclimatization in a hot, dry (desert type) environment. Am J Physiol. 1950;163:585-97.

54 Midgley AW, McNaughton LR, Wilkinson M. Is there an optimal training intensity for enhancing the maximal oxygen uptake of distance runners? Sports Med. 2006;36:117132.

55 Hue O, Antoine-Jonville S, Sara F. The effect of 8 days of training in tropical environment on performance in neutral climate in swimmers. Int $\mathrm{J}$ Sports Medicine. 2007;28:48-52.

56 Morrison JP, Hopkins WG, Sleivert GG. Little effect of training in the heat on cycling. Sportscience. 2002. http://www.sportsci.org/jour/0201/jpm.htm. Accessed $18^{\text {th }}$ Feb 2014.

57 Taylor NA, Cotter JD. Heat adaptation: guidelines for the optimisation of human performance: review article. Int SportMed J. 2006;7:33-57.

58 Shapiro Y, Hubbard RW, Kimbrough CM, et al. Physiological and hematologic responses to summer and winter dry-heat acclimation. J Appl Physiol. 1981;50:792-798. 
59 Hopkins WG, Hawley JA, Burke LM. Design and analysis of research on sport performance enhancement. Med Sci Sports Exerc. 1999;31:472-485.

60 Bassett JR, Kyle CR, Passfield L, et al. Comparing cycling world hour records, 19671996: modelling with empirical data. Med Sci Sports Exerc. 1999;31:1665-1667.

61 Atkinson G, Davison R, Jeukendrup A, et al. Science and cycling: current knowledge and future directions for research. J Sport Sci, 2003;21:767-787.

62 Garrett AT, Goosens NG, Rehrer NJ, et al. Short-term heat acclimation is effective and may be enhanced rather than impaired by dehydration. Am J Hum Biol. 2014 doi: 10.1002/ajhb.22509

63 Tipton M. A case for combined environmental stressor studies. Extrem Physiol Med. 2012;1:1-2. 